\title{
Desenvolvimento territorial sustentável e desafios postos por megaempreendimentos: o caso do município de Itaguaí - RJ
}

\author{
Sustainable territorial development and challenges posed by mega-projects: the case of the \\ city of Itaguaí - RJ
}

\author{
Jeferson Simões Santana ${ }^{1}$ \\ Cezar Augusto Miranda Guedes² \\ Lamounier Erthal Villela ${ }^{3}$
}

\section{Resumo}

O artigo tem o objetivo de avaliar a ação dos poderes públicos locais e da sociedade civil na construção da sustentabilidade territorial, face aos processos de implantação de megaempreendimentos no município de Itaguaí-RJ. Para tal, descreve os impactos das transformações trazidas pelos grandes empreendimentos no território em análise. Examina-se a atuação dos poderes locais para mitigar os efeitos indesejáveis e irrigar aqueles aspectos do crescimento favoráveis a uma melhoria das condições de vida e sustentabilidade do município. Como resultado, verifica-se a carência de instrumentos para o tratamento técnico e político ao lado dos interesses e estratégias do poder central e dos capitais envolvidos, principalmente quanto à capacidade de monitorar as ações, tendo em vista aspectos como as discrepâncias entre o período dos mandatos para prefeitos e o planejamento de longo prazo mantido pelas empresas. Também foi observada a falta de articuladores locais capacitados em fomentar ações em prol da governabilidade, da gestão social participativa, da coesão social e territorial, da sustentabilidade, da inclusão econômica e de bem estar no território em questão.

Palavras-chave: Itaguaí. Desenvolvimento territorial. Desenvolvimento sustentável. Megaempreendimentos.

Artigo submetido em 14 de março de 2011 e aceito para publicação em 16 de agosto de 2011.

1 Mestre pelo Programa de Pós-graduação em Gestão e Estratégia de Negócios da Universidade Federal Rural do Rio de Janeiro (PPGEN/UFRRJ). Endereço: Campus UFRRJ - ICHS/DECECON, BR-465, Km 7, CEP 23890-000, Seropédica, Rio de Janeiro - RJ, Brasil. E-mail: jefsan@gmail.com

2 Pós-doutor pelo Instituto Superior de Economia e Gestão/Universidade Técnica de Lisboa (ISEG/UTL), Portugal; Doutorado em Administração pela EAESP/FGV; Professor Associado da Universidade Federal Rural do Rio de Janeiro (UFRRJ/DECECON/PPGEN/PPGCTIA). Endereço: Campus UFRRJ, ICHS/DECECON BR.465, Km 7, CEP 23890-000, Seropédica, Rio de Janeiro - RJ, Brasil. E-mail: cguedes@ufrri.br

${ }^{3}$ Pós-doutor em Administração Pública pela EBAPE/FGV; Doutor em Economia Aplicada pela Université de la Sorbonne Nouvelle (Paris III); Professor Adjunto da Universidade Federal Rural do Rio de Janeiro (UFRRJ/DECECON/PPGCTIA). Endereço: Campus UFRRJ, ICHS/DECECON BR.465, Km 7, CEP 23890-000, Seropédica, Rio de Janeiro - RJ, Brasil. E-mail: lamounier@ufrri.br 


\begin{abstract}
This article aims to study the role of local authorities and civil society in building territorial sustainability in the implementation processes of mega-projects in the town of Itaguaí-RJ. Therefore, it describes the impact of changes brought about by large enterprises in the territory under study. It examines the role of local governments when it comes to mitigating the undesirable effects and giving a boost to those aspects of growth that help to improve living conditions and the sustainability of the town. As a result there is a lack of instruments for dealing with technical and political interests and strategies of the central government and capital involved, especially regarding the ability to monitor actions involving issues such as discrepancies between the duration of mandates for mayors and maintained long-term planning by firms. The study also found a shortage of trained local organizers to promote actions in support of governance, participatory social management, social and territorial cohesion, sustainability, inclusion and the economic well being of the territory in question.
\end{abstract}

Keywords: Itaguaí. Territorial development. Sustainable development. Mega-projects.

\title{
Introdução
}

O Estado do Rio de Janeiro, segundo maior Produto Interno Bruto (PIB) dentre as 27 unidades federativas do Brasil, tem sido foco de grandes empreendimentos, sejam novos ou expansão de antigos. No município de Itaguaí, objeto deste artigo, temos que destacar, entre outros grandes investimentos, a implantação da Companhia Siderúrgica do Atlântico (TKCSA) e a consolidação de dois vetores logísticos: a revitalização do porto de Itaguaí e a construção do arco rodoviário. Segundo o Instituto Brasileiro de Geografia e Estatística (IBGE), Itaguaí possui 105.633 habitantes, com Índice de Desenvolvimento Humano (IDH) de 0,768, ocupando a $42^{\mathrm{a}}$ posição entre 92 municípios do Estado do Rio de Janeiro e $1376^{\mathrm{a}}$ dentre os 5.564 municípios brasileiros (CIDE RJ, 2008). O município faz parte da mesorregião Metropolitana do Rio de Janeiro (Figura 1), área com população total de cerca de 13 milhões de habitantes. Em termos geográficos, dista de $400 \mathrm{~km}$ da cidade de São Paulo, maior centro industrial do país (IBGE, 2008).

Desde os anos setenta do século passado, Itaguaí tem sido palco de lançamentos de projetos capitaneados por diferentes governos e por ações de empresas privadas. Nos anos 70, o governo federal implantou o porto de Sepetiba, atualmente denominado de porto de Itaguaí. Devido às excelentes condições de navegação existentes na baía de Sepetiba, bem como de aspectos logísticos favoráveis proporcionados por sua localização geográfica, o porto vem continuamente recebendo novos investimentos de ampliação (MULS, BÉCUE e MELO, 2005) Também nos anos 70, foi instalada em Itaguaí, a empresa Nuclebrás Equipamentos Pesados S.A. (NUCLEP) como parte do Programa Nuclear Brasileiro. Nos anos 80, outra decisão impactante para o município foi tomada pela empresa Petróleo Brasileiro S.A. (PETROBRAS), que reservou uma área no município de quase 12 milhões de metros quadrados para instalação de um polo petroquímico.

No início dos anos 2000, a região, e principalmente o munícipio de Itaguaí, revivem a expectativa de desenvolvimento socioeconômico como já the tinha sido prometido no século passado. Atualmente, Itaguaí conta com diversos empreendimentos em diferentes fases de instalação e de funcionamento. O Porto de Itaguaí tem, em andamento, obras de ampliação da área de manobra do porto com dragagens destinadas a assegurar um calado de 20 metros de profundidade que permite acesso de navios mercantes de grande porte. Também a construção de novos terminais para o Grupo EBX, para a Companhia Siderúrgica Nacional (CSN), para a TKCSA, além de outros dois terminais que serão operados pela Companhia Docas do Rio de Janeiro (CDRJ). Por si só, estas obras comporão um valioso canal logístico para a economia brasileira e confirmarão a sua vocação antiga de hub port, ou seja, porto concentrador de navios de grande porte destinado ao comércio internacional. Estes empreendimentos envolvem cerca de US\$ 4 bilhões, 18 mil empregos na fase de construção dos terminais e previstos quatro mil empregos na fase de operação. 
Figura 1

\section{Mesorregião Metropolitana do Rio de Janeiro}

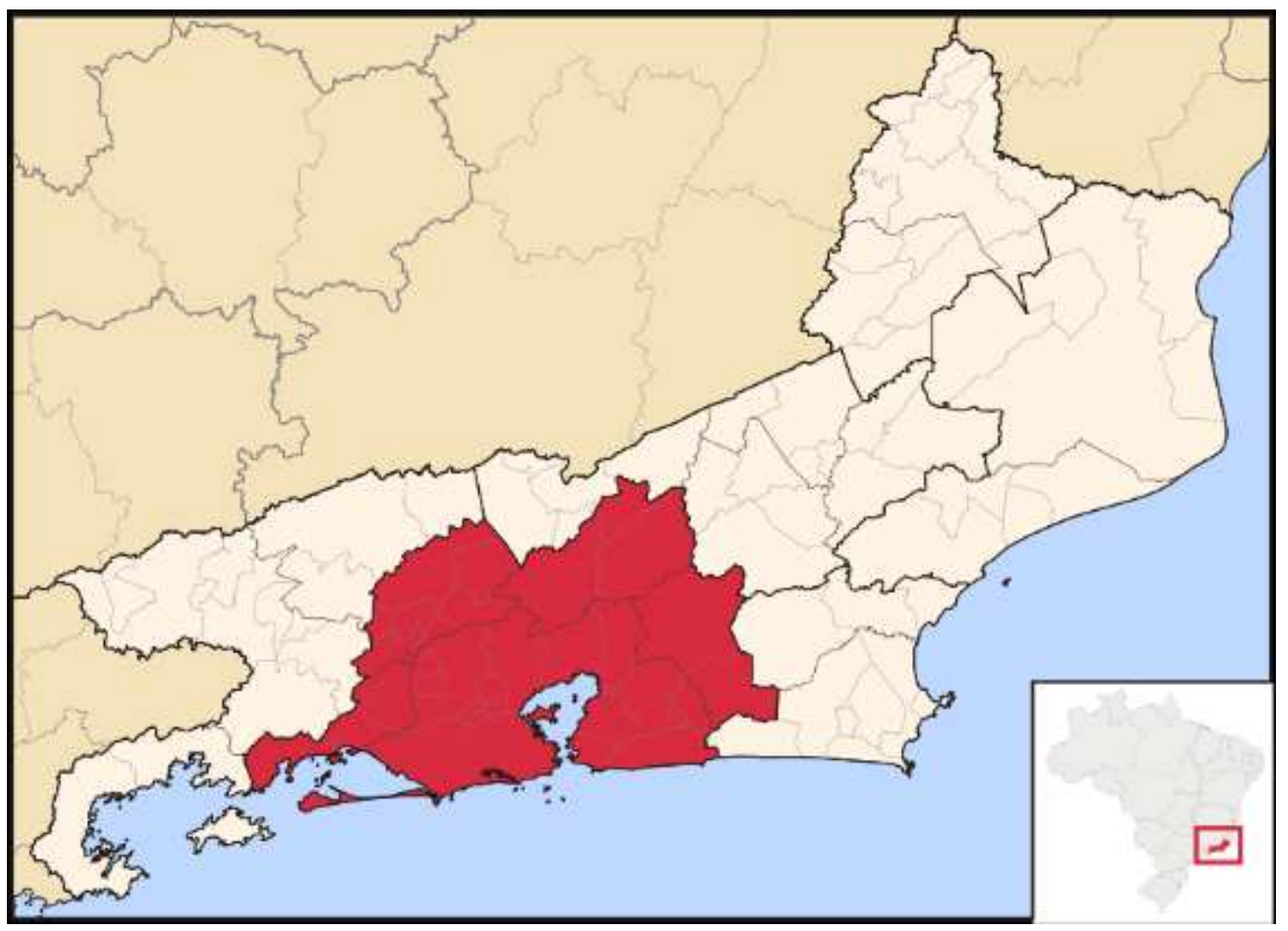

Fonte: extraído de CIDE-RJ, (2010).

Outros investimentos, indiretamente relacionados ao porto, estão em andamento, cabendo destacar: a duplicação da rodovia BR-101, no trecho entre a cidade do Rio de Janeiro e o distrito de Itacuruçá, em Mangaratiba, atravessando todo o município de Itaguaí. Essa obra pretende desafogar o trânsito no trecho inicial da rodovia Rio-Santos, contribuindo para facilitar o acesso ao porto de Itaguaí; a construção do Arco Metropolitano (ver Figura 2), com uma extensão de 145 quilômetros, ligando o Complexo Petroquímico do Rio de Janeiro (COMPERJ), situado no município de Itaboraí/RJ ao porto de Itaguaí; a construção da siderúrgica da Thiessen-Krupp Companhia Siderúrgica do Atlântico (TKCSA), na divisa com o município de Itaguaí e que terá como suporte logístico de entrada principal a ferrovia e de saída o porto de Itaguaí. Este empreendimento, inaugurado oficialmente em junho de 2010, envolve cerca de R\$11,4 bilhões, 18 mil empregos na construção e 3,5 mil na operação (BUENO, 2009).

Em agosto de 2010, a Marinha brasileira iniciou a construção de um estaleiro para construir submarinos atômicos na ilha da Madeira em Itaguaí, em parceria com o Governo Francês. O canteiro de obras possui 90 mil metros quadrados e 320 trabalhadores da Construtora Odebrecht. Trata-se da Unidade de Fabricação de Estruturas Metálicas (UFEM), primeira etapa do novo Complexo Militar-Naval. Além da UFEM, o Complexo é composto por um Estaleiro e pela Base Naval de Submarinos. 
Figura 2

\section{Rodovia Arco Metropolitano do Rio de Janeiro}

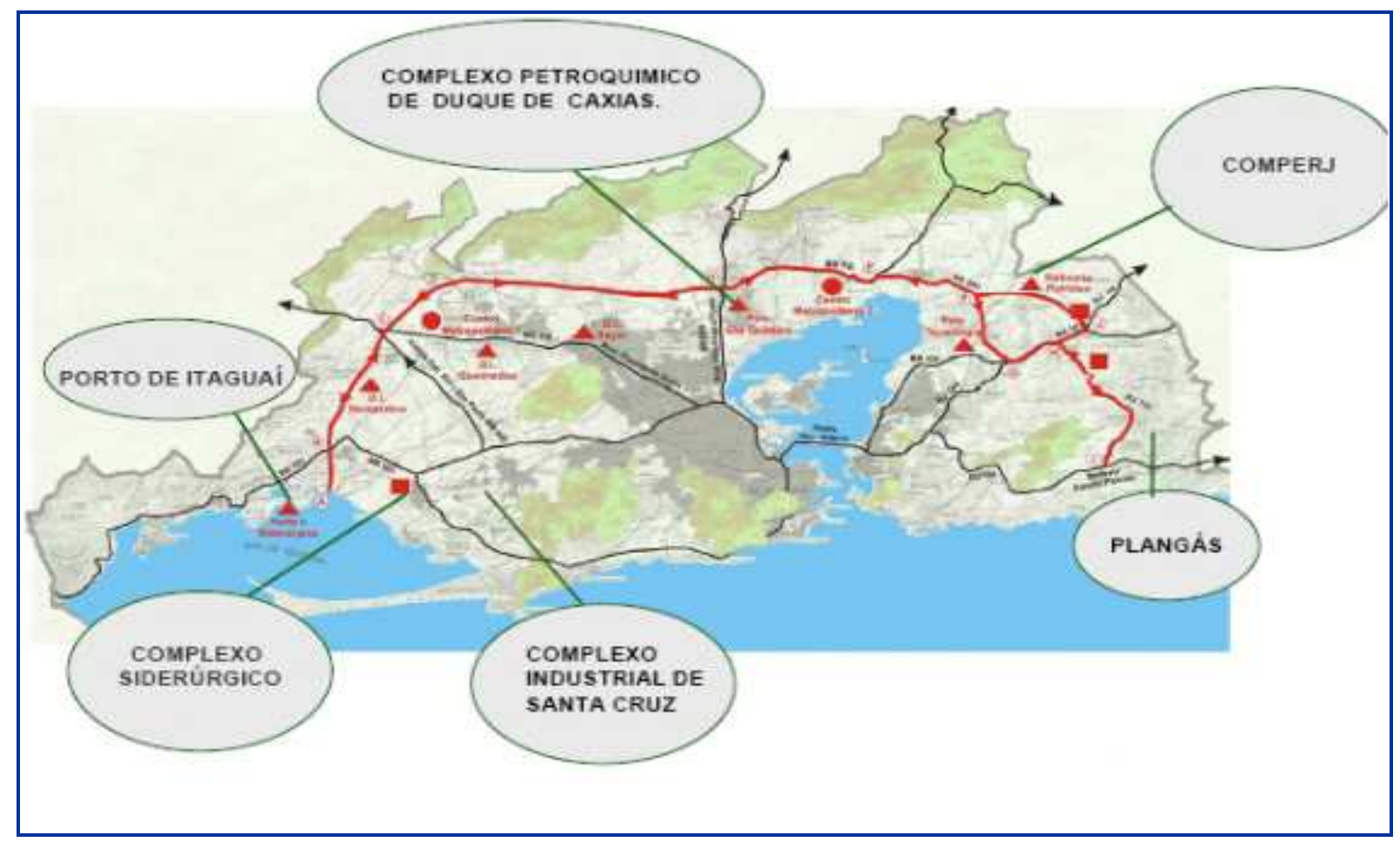

Fonte: Extraído de CIDE-RJ, (2010).

De acordo com Bueno (2009), no conjunto, estes projetos representam o maior pacote de investimentos privados em curso no Brasil. Considerando a questão colocada por Vainer (2001), "o que pode o poder local?", poderíamos aqui perguntar: o que pode fazer o poder local de Itaguaí para defender os interesses de sua cidade e de seus cidadãos frente ao estabelecimento de grandes empreendimentos, cujos objetivos, planos e lucros estão localizados alhures, mas cujas consequências econômicas, físicas e sociais estão aqui localizadas? A implantação de grandes empreendimentos em cidades com um perfil histórico não industrial costuma ser vista pelos cidadãos locais como um movimento de "salvação", na expectativa de investimentos e empregos. Em muitos casos, tal afirmação não é verdadeira, pois existem diversos exemplos e estudos que descrevem as consequências, muitas vezes funestas, que acontecem ao local alvo do empreendimento (LOLLO e RÖHM, 2005). Em Itaguaí, tal processo está em curso, e talvez seja possível identificar as eventuais decorrências negativas para o local, antes que se desdobrem de forma permanente. A implantação destes empreendimentos representa o início de muita "coisa nova", outro quadro socioeconômico com positividades e negatividades igualmente impactantes.

Logo, o objetivo deste artigo consiste em descrever as transformações em curso trazidas pelos grandes empreendimentos, e examinar a atuação e as possibilidades de atuação do poder local (poder público local, sociedade civil e mercado) no que concerne a suas formas de participação nos processos decisórios locais. Para tal, a pesquisa investigou: a atuação do poder local frente aos desafios trazidos por estes empreendimentos; e a capacidade dos instrumentos disponíveis do poder local para o tratamento técnico e político junto dos interesses e estratégias do poder central e dos capitais envolvidos, principalmente quanto à capacidade de monitorar as ações. Segundo Furtado (2000, p. 22), o desenvolvimento é "o processo de invenção cultural que permite ver o homem como um agente transformador do mundo". Não se pode esquecer de que, frequentemente, o grande investimento decorre de associação de interesses estratégicos entre a empresa e o poder central. Mesmo que o poder político não esteja formalmente associado ou atrelado 
ao interesse empresarial, é fato que a empresa traz emprego, renda e impostos. Esses são pontos buscados pelos governos, ainda que não tenham propriamente uma visão do resultado social. A suposição que norteou a pesquisa que deu origem a este artigo é que o poder local, no caso de Itaguaí, não dispõe de ferramentas adequadas ao trato com grandes empreendimentos, o que estabelece assimetrias de informações e de relações de poder. Tais assimetrias colocam em desvantagem os poderes locais, sejam públicos ou da sociedade civil, que agem na maioria das vezes como meros espectadores das transformações em curso no seu território. Esta postura passiva face às transformações é inerente a pouca participação dos poderes locais nos processos deliberativos.

\section{Fundamentação teórica}

\section{Desenvolvimento local}

Desde as últimas décadas do século $\mathrm{XX}$, a discussão sobre desenvolvimento local e poder local tomou forma mais ampla, em parte devido às dificuldades do modelo de desenvolvimento decorrente de iniciativas do estado central e, em parte, como uma forma de compensar a influência econômica, política e cultural do movimento globalizante. Desde essa época se discute a validade e efetividade do desenvolvimento local, visto como uma forma de organização dos agentes e recursos de um local em busca de um desenvolvimento justo e sustentável. Em contraponto a uma longa predominância dos modelos de desenvolvimento econômico regional, originados nos centros planejadores, o modelo de desenvolvimento local busca outra ordenação: na França, com uma visão focalizada no papel do cidadão e com uma visão integral do território, e na Itália, onde pequenas e médias empresas de um mesmo segmento econômico buscam criar economias de escala e aproveitar as sinergias da proximidade. Essas experiências, repetidas e ampliadas em diversos países, afirmam a validade do modelo de desenvolvimento local. (GARCES e SILVEIRA, 2002, p. 67)

Estudos têm sido desenvolvidos no Brasil e na América latina, examinando as diversas facetas e características do desenvolvimento local. Estudando o fenômeno, (OLIVEIRA, 2002) analisa o desenvolvimento local como sendo composto de três dimensões básicas: a primeira dimensão refere-se à capacidade efetiva de participação da cidadania. Essa participação afirma e resgata a atuação e responsabilidade do cidadão na construção do governo, haja vista que a democracia representativa estabelece grande distância entre o governante e aqueles que nele votaram, durante o exercício do poder. A segunda dimensão, ponto essencial, refere-se à possibilidade de que haja na correção da tendência de concentração que, segundo Oliveira (2002), parece inerente ao processo capitalista no nível macro. Esse aspecto parece indicar que o desenvolvimento local dá oportunidades a que empreendimentos de pequeno e médio porte recebam guarida para se estabelecer. Como terceira e última dimensão, estabelecer-se-ia um contraste entre a globalização e o desenvolvimento local. Esses aspectos se constituiriam em elementos essenciais à caracterização de desenvolvimento local. Este tipo de ação deve criar condições a uma participação efetiva do cidadão, possibilitar o surgimento de pequenos e médios empreendimentos, como forma de compensar a vantagem inerente ao grande empreendimento e ser um modo de afirmação do local frente à dinâmica de globalização. Todo esse processo tem lugar em determinado tempo e espaço. Logo, quando falamos de desenvolvimento local, estamos nos referindo a um processo que se verifica em determinado espaço territorial demarcado em sub-regiões, municípios e cidades (TENÓRIO, 2007, p. 17).

O desenvolvimento como um processo engloba as diversas dimensões da região enfocada e não apenas a econômica, mais comumente observada quando se fala sobre o assunto. As dimensões social, ambiental, cultural, físico-territorial, político-institucional e científico-tecnológica são facetas de um mesmo complexo processo de desenvolvimento. Tal visão é compartilhada por outros autores, como contextualiza BresserPereira (2003, p. 31): 
O desenvolvimento é um processo de transformação econômica, política e social, através do qual o crescimento do padrão de vida da população tende a tornar-se automático e autônimo. Trata-se de um processo global, em que as estruturas econômicas, políticas e sociais de um país sofrem contínuas e profundas transformações. Não tem sentido falar-se em desenvolvimento apenas econômico, ou apenas político, ou apenas social. Não existe desenvolvimento dessa natureza, parcelado, setorializado, a não ser para fins de exposição didática. Se o desenvolvimento econômico não trouxer consigo modificações de caráter social e político, se o desenvolvimento social e político não for a um tempo o resultado e a causa de transformações econômicas, será porque de fato não tivemos desenvolvimento. As modificações verificadas em um desses setores terão sido tão superficiais, tão epidérmicas, que não deixarão traços.

A expressão desenvolvimento local busca também caracterizar o processo de crescimento que se dá pela atuação do estado e não apenas pelas forças do mercado. Não é algo que ocorra de forma espontânea. É processo provocado e que deve ser gerenciado, procurando reforçar a potencialidade do território mediante ações endógenas, articuladas por seus diferentes atores: sociedade civil, poder público e o mercado. Oliveira (2002) também observa que a associação adequada do desenvolvimento local com empreendimentos estruturantes do desenvolvimento nacional pode resultar em resposta mais efetiva aos desafios do desenvolvimento em regiões mais carentes. Esse ponto tem relevância, haja vista que o processo de desenvolvimento local está inserido em contexto regional e nacional. As ações estratégicas de escalas maiores podem afetar o que se passa no local.

Por outro lado, considerando a extraordinária complexidade do ambiente socioeconômico em qualquer escala de poder, Levy (2002) aponta para a evidência de que o poder público não pode mais agir isolado, sem considerar a necessidade de se estruturar numa rede de parceiros estatais, não estatais e privados, no qual cada um tem possibilidade de interferir no andamento do processo. De forma geral, o desenvolvimento local induz à busca de evitar a repetição das desigualdades de recursos, poder, formas sociais e exploração dos recursos naturais, presentes no modo de produção econômico (CALDAS e MARTINS, 2004).

Vainer (2001, p. 17) sumariza a discussão das escalas de atuação do poder local:

Podemos observar que a questão da escala na atuação política é crucial. Parte da discussão defende a busca de uma atuação em escala global da cidadania, como forma de estar no mesmo nível das decisões que são tomadas pelos agentes globalizados. Não há dúvida que grande parte das decisões que afetam as vidas do cidadão comum são tomadas e executadas sob uma ótica global. Por outro lado, uma significativa parcela dos estudiosos defende a maior importância da atuação local, como complemento da visão globalizada, pois argumentam que o governo local tem maiores condições de atuar de forma eficaz para atrair empresas, promover sua competitividade e oferecer a base histórica e cultural para a integração dos indivíduos.

Segundo Vainer (2001), diversos estudiosos do assunto defendem que a abordagem deve ser feita de forma transescalar: "qualquer projeto (estratégia?) de transformação envolve, engaja e exige táticas em cada uma das escalas em que hoje se configuram os processos sociais, econômicos e políticos estratégicos" (VAINER, 2001, p. 25). Nessa linha de argumentação, a força da atuação das multinacionais está mais presente na capacidade de atuação nas diferentes escalas e menos em sua globalidade. A mobilização de recursos complementares em diferentes regiões nas quais a multinacional atua pressupõe uma grande capacidade de articulação das diferentes escalas de poder. Esse seria o real poder à disposição da grande empresa.

A partir da segunda metade da década de 90, o local assume a preponderância entre as escalas, na tarefa de gerir as contradições referentes ao desenvolvimento. A visão local chega a ser considerada por muitos como 
a única forma legítima de definir os problemas do desenvolvimento. Essa nova marca de atuação é vista como decorrente da crise do Estado-Nação, não mais visto como moldura organizacional da definição do social, bem como das críticas à concepção de desenvolvimento centrada no estado. (CARAMELO e CORREIA, 2004). Não sendo o estado mais confiável na interpretação das necessidades e na execução das ações desenvolvimentistas, buscam-se soluções endógenas e localistas, no pressuposto que tal perspectiva próxima contribua para melhoria do processo.

Embora assumindo o protagonismo, a escala local/regional não é suficiente para manter-se ou desenvolver-se isoladamente. Não há um poder estruturalmente local, seja de caráter privado ou público: há atuação de dimensões locais de um poder construído pelas complexas relações entre diferentes escalas dos tomadores de decisão, tanto no âmbito privado como no público (ACSELROD, 2002). A preponderância do processo de desenvolvimento local é fruto de um complexo de interações entre aspectos de resposta aos problemas da globalização, de ocupação de espaços de desenvolvimento deixados pelo estado central e também um relativo aumento da consciência de capacidade de atuação dos atores locais. Todos os fatores interagem na criação de um ambiente no qual a atuação do desenvolvimento local é esperada e possível (ACSELROD, 2002). O local também propicia uma concentração de atividades que seriam ligadas a economias de aglomeração, em um processo cumulativo de vários fatores: economias de escala, custos de transporte, relações entre empresas, especialização, criação de redes e parcerias e diversos outros aspectos que aumentam a produtividade do conjunto econômico local (KRUGMAN, 1991).

O esquema apresentado por Albuquerque (2004), após estudar experiências latino-americanas, traz a seguinte perspectiva:

[...] elementos básicos das iniciativas de desenvolvimento econômico local: a mobilização e a participação dos atores locais; a postura proativa do poder público local; a existência de grupos de liderança local; a cooperação público-privada; a elaboração de uma estratégia territorial de desenvolvimento; o apoio às Micro, Pequenas e Médias Empresas (financeiro e capacitação); a coordenação de programas de ação e dos instrumentos de apoio; e a institucionalização do quadro para o desenvolvimento local, ou seja, a busca de um pacto político suprapartidário no âmbito territorial para assegurar a legitimidade e durabilidade em outros termos a sustentabilidade - do processo, para além das mudanças políticas. (ALBUQUERQUE, 2004, p. 11).

Quanto ao aspecto relativo à presença de grandes empreendimentos e como eventualmente impactam as condições do local, Pires e Pedlowski (2009), estudando a instalação do complexo portuário da Barra do Açu, no norte do Estado do Rio de Janeiro, comentam:

No entanto, toda a evolução institucional e difusão social do conceito de sustentabilidade estão sendo colocadas em xeque pela implantação de megaempreendimentos que vêm surgindo em diferentes partes do planeta. No caso brasileiro, a retomada de modelos de natureza teoricamente desenvolvimentista (mas que na prática reproduzem a lógica tradicional da primazia do crescimento econômico) pelo governo Lula tem implicado no surgimento de uma série de empreendimentos cuja magnitude coloca em risco a existência de comunidades tradicionais e dos ecossistemas de que estas dependem para sobreviver. Alerta que estes megaempreendimentos também implicam no aumento das tensões e conflitos sociais, visto que geram uma inevitável disputa por territórios por agentes que operam a partir de diferentes escalas espaciais, e municiados de diferentes níveis de poder político e econômico (PIRES e PEDLOWSKI, 2009, p. 23).

Examinando a questão da localização do empreendimento em determinado local fora de sua origem, a teoria da internacionalização da produção informa que há três formas básicas da internacionalização: comércio, 
investimento externo direto e relações contratuais. A lógica que conduz a uma decisão de internacionalizar, isto é, no caso, produzir em determinado local, fora da origem da empresa, envolve verificar se a empresa tem expectativas de lucro acima do normal com a decisão; definir a forma concreta de internacionalização, seja mediante comércio, investimento externo direto ou relações contratuais; e em terceiro aspecto, devem ser examinados os fatores locacionais específicos.

Nesses aspectos, são consideradas dificuldades ou facilidades de mercado, estabilidade do ambiente legal e econômico, disponibilidade de tecnologia e infraestrutura econômica e diversos outros. Essas decisões sem dúvida são cheias de riscos e incertezas, porém o fator motivador principal é a característica do agente econômico de se comportar de "natureza oportunista", pois busca o máximo de benefício com o mínimo de custo (GONÇALVES, 2005, p. 108-113).

Portanto, no cerne da decisão de determinado empreendimento localizar-se num certo local do sudeste do Brasil em vez de em seu lugar de origem ou em qualquer outro lugar, está o fato de que as vantagens disponibilizadas para aquele local específico se apresentam de forma superior na busca de assegurar o lucro. Essas vantagens são normalmente associadas ao custo reduzido dos salários, terras ou taxas e em muitas oportunidades, isenções e esquemas de financiamentos públicos em suas diversas escalas, potencializando assim a rentabilidade derivada das decisões de investimento e suas lógicas espaciais.

Como um contraponto às abordagens que consideram a capacidade de ação dos poderes locais no desenvolvimento local, também adverte Fischer, (2002, p. 99):

Desgaste conceitual do próprio termo "desenvolvimento local", devido à amplitude de emprego, gerando um vazio conceitual. Em diversos contextos políticos é utilizado como peça de marketing. Desgaste dos métodos participativos, pela ausência de planos de ação estruturados e escassez de resultados; o meio de participação utilizado para estabelecer apenas um compromisso do cidadão; a articulação de comunidades de interesses esbarra em limites concretos de poder, por exemplo, o consenso quanto à necessidade de aumento de emprego e renda esbarram nos limites do Estado e do mercado. A descontinuidade política e as interferências político-partidárias locais ou não; a rotatividade necessária no poder e a pouca profissionalização da administração pública conduz à descontinuidade de políticas e em muitos casos, a intencional desmontagem do trabalho construído por uma administração anterior. Dificuldades de articulação entre governo/governo, governo e sociedade e sociedade/sociedade, devido a fatores culturais ou de imaturidade democrática. As relações entre as escalas de governo sofrem interferência de questões partidárias, enquanto no caso da participação da sociedade, as questões relativas ao aspecto da imaturidade democrática sobressaem. Tendência à construção "externa" das estratégias de desenvolvimento local, por agências, ONGs e governo. Fragilidades metodológicas dos tipos de intervenção em desenvolvimento local; interesses nos agentes promotores do desenvolvimento local, que criam dependências nas comunidades apoiadas. Nesse caso, encontram-se dificuldades devidas ao interesse empresarial das consultorias em manter a dependência; superposição de programas e projetos de diferentes instituições; avaliação inexistente ou inadequada dos processos, resultados e impactos.

Ainda, segundo Tenório (2007), quando se aborda o tema Desenvolvimento Local, devem-se considerar todos os aspectos de inter-relacionamento dos diversos atores da sociedade. Assim sendo, torna-se necessária uma profunda transformação das relações sociais, ou seja, a ampliação da racionalidade substantiva referente às práticas locais. Reitera o autor:

Não devem ser enfocados apenas os processos sociais e técnicos de produção, mas sim, a preservação ambiental também, pois os programas e projetos de desenvolvimento 
objetivam assegurar melhores condições materiais como a sustentabilidade do território de acordo com as condições, possibilidades e vocações do mesmo. (TENÓRIO, 2007, p. 4).

Neste contexto, existe uma mudança nas relações políticas locais, pois os processos de desenvolvimento local interdependem dos esforços exercidos tanto pelas entidades estatais quanto pela sociedade, visto que ambos deverão estar focados em levar adiante projetos surgidos de interesses coletivos, oriundos das discussões e da prática dialógica. Neste sentido, o desenvolvimento local necessita de ações de cidadania, ou seja, o reconhecimento por parte dos agentes de como suas ações irão influenciar na valorização dos recursos e potencialidades do território em questão e como estas ações irão promover a qualidade de vida da população. Se as ações do desenvolvimento local são interdependentes das forças locais e estas representam o desejo e a capacidade dos atores locais em formular e implementar ações que elaborem mudanças no status quo.

No sentido de pensar desenvolvimento local com inclusão social, o conceito de Desenvolvimento Territorial Sustentável (DTS) (PERICO, 2009), vem sendo discutido e aplicado pela Secretaria de Desenvolvimento Territorial do Ministério do Desenvolvimento Agrário. Logo, importa ao DTS, o território, sua identidade, sua cultura, suas relações econômicas e sociopolíticas. O território significa um "espaço" ocupado por uma determinada população que o controla, tanto as fronteiras geográficas como as relações simbólicas, observando as seguintes dimensões, abaixo descritas: a coesão social, que consiste na congruência da população local, ou seja, no fortalecimento de seus laços interpessoais a fim de favorecer e capacitar o potencial de equidade dos direitos e obrigações cidadãs; a coesão territorial, que se refere à capacidade da população de um território ter densidade nas relações interpessoais para definir suas políticas, suas estratégias em função de seus próprios recursos e interesses territoriais; a governabilidade, que se refere à capacidade dos poderes públicos em agir com objetivos e propósitos de desenvolvimento local; a sustentabilidade: as atividades econômicas atuais não podem colocar em risco o bem comum nem as atividades econômicas de futuras gerações; a inclusão econômica é a capacidade pela qual o desenvolvimento local inclui a população economicamente ativa em suas atividades de modo contínuo e permanente; e por último o bem-estar que o desenvolvimento do local proporciona sobre as condições de vida da população agregando infraestrutura, saneamento, instituições de saúde e de educação.

\section{Gestão social}

Em alguns contextos a gestão social é associada a políticas de combate à pobreza, à administração da chamada área social (saúde, educação, assistência social, meio ambiente bem como à gestão de organizações do terceiro setor. Uma política pública é caracterizada pela ação deliberada do poder público com vistas de antecipar necessidades, como no caso de ações e planos que busquem criar condições propícias ao desenvolvimento socioeconômico de determinado local, região ou país. No contexto deste trabalho, a gestão social está associada a uma gestão pública que considera essencial a participação dos diversos atores interessados em determinada ação pública. Visa evitar que a gestão venha privilegiar interesses do Estado, representado por outras esferas de governo ou do mercado, em sua concepção mais ampla. É necessário portanto, desde as fases iniciais de planejamento e decisão, haver uma comunicação dialógica entre os interessados, de forma a criar um consenso entre os atores (TENÓRIO, 2007).

Portanto, a gestão social não está restrita à gestão da área social ou a uma gestão voltada para o social e associada a um processo de gestão pública que tem como perspectiva determinante de suas ações a sociedade e não o mercado (TENÓRIO, 2009). É o processo de gestão que em sua forma considera os interesses dos atores locais da sociedade, do mercado e do governo como essenciais. É o instrumento na gestão pública para concretizar a política de desenvolvimento local com cidadania. Nesse sentido, a gestão social é como é chamado conjunto de processos sociais em que a ação gerencial se desenvolve através de uma ação 
negociada entre seus atores. Tais processos não têm um caráter burocrático, pois há uma relação direta entre o processo administrativo e a múltipla participação dos atores.

Chamamos aqui de instrumental do poder local aquelas formas de participação dos diferentes atores do desenvolvimento local, que são também conhecidos como meios de participação, assegurados em grande parte pela Constituição Federal de 1988 (BRASIL, 1988). São as formas legais, governamentais ou não que possibilitam que o poder local, em suas diferentes facetas de atuação, possa agir, no sentido de interferir nos rumos do desenvolvimento local (TENÓRIO, 2007). Estão citados os itens da Constituição Federal mais diretamente ligadas ao poder local:

Ação popular (art. $5^{\circ}$, LXXIII): qualquer cidadão pode propor ação popular para anular ato danoso da administração pública.

É dever da família, sociedade e estado assegurar os direitos da criança e adolescente (art. 227 , caput e $\S 7^{\circ}$, que remete ao art. 204, II).

Colegiados de Órgãos Públicos (art.10): assegura a participação de trabalhadores e empregadores nos colegiados de órgãos públicos.

Cultura (art. 216, § $1^{\circ}$ ): prevê a participação da comunidade na defesa e promoção do patrimônio cultural.

Denúncia de irregularidades/ilegalidades (art. $74, \S 2^{\circ}$ ): qualquer cidadão, partido político, associação ou sindicato pode denunciar irregularidades ou irregularidades perante o Tribunal de Contas da União.

Ensino Público (art. 206, VI): admite-se, em caráter genérico, a gestão democrática do ensino publico, remetendo-se à lei sua regulamentação. O Ensino Público deve responder aos desafios locais.

Iniciativa Popular (art. 14, III, $27 \S 4^{\circ}, 29$, XIII e $61 \S 2^{\circ}$ ): meio de participação popular no processo legislativo, através da apresentação de projetos de lei para apreciação do Poder Legislativo.

Planejamento Público (art.29, XII): estabelece a obrigatoriedade de participação no planejamento público, em nível municipal, das associações representativas.

Plebiscito (art. 14, I, 18, $\S 3^{\circ}$ e $4^{\circ}$ e $49, \mathrm{XV}$ ): consulta popular semelhante ao referendo.

Política agrícola (art. 187): determina que toda política agrícola deverá ser planejada e executada com a participação efetiva do setor de produção, envolvendo produtores e trabalhadores rurais, bem como dos setores de comercialização, de armazenamento e de transportes.

Referendo (art. 14, II e 49, XV): forma de consulta popular em que os projetos de lei aprovados pelo legislativo devem ser submetidos à aprovação popular para que possam entrar em vigor. 
A par da lei, temos iniciativas diversas como:

- Agência de desenvolvimento local: Instituição civil de direito privado, sem fins lucrativos, que tem por objetivo gerar oportunidades de negócios, promover parcerias entre empresas e/ou entidades, elaborar projetos e realizar articulação com o poder público.

- Agenda 21 Local: é processo de desenvolvimento de políticas para o alcance da sustentabilidade, cuja implementação depende, diretamente, da construção de parcerias entre poder público local e sociedade civil (MMA, 2004).

- Conferência: Conferências são convocadas pelo Poder Executivo para debater reivindicações e formulação de políticas setoriais.

- Conselhos: Os conselhos são instâncias de formação de políticas que gozam de um alto conceito de respeitabilidade enquanto espaços transparentes e comprometidos com o interesse público, espaços que tornam a política mais pública, pelo menos aqueles em que há participação de grupos sociais organizados e democráticos (CARVALHO, 1998).

- Consórcios intermunicipais: entidades que viabilizam ações conjuntas de vários municípios.

- Desenvolvimento Local Integrado e Sustentável (DLIS): forma de condução de desenvolvimento que busca facilitar a participação coletiva, mediante parcerias entre os atores da sociedade civil, de governos e empresas.

- Fóruns: espaço de participação e elaboração de projetos de desenvolvimento local.

- Orçamento participativo

- Parcerias: têm como objetivo dividir o poder de decidir entre instituições parceiras e assim conseguir melhor capacidade de atuação. Geralmente efetivado entre movimentos ou Organizações Não Governamentais (ONGs), empresas e poder público. Seu sucesso depende da capacidade de diálogo entre os parceiros.

- Estatuto da Cidade (Artigos 182 e 183 da CF e Lei 10257/2001) e Plano Diretor: define a função social da propriedade urbana e busca assegurar o atendimento das necessidades dos cidadãos quanto à qualidade de vida, desenvolvimento de atividades econômicas e justiça social (FRANÇA, 2009).

- Plano estratégico local: modelos de planejamento local, em que os planos do governo dão espaço para participação dos atores locais.

- Polo de desenvolvimento: geralmente associados a investimentos em determinada área que se distingue pela capacidade de induzir transformações na sua área de influência.

- Redes: conjunto de nós interconectados, normalmente originados em torno de objetivos comuns que se mantêm unidos e participantes devido a uma estrutura de comunicação comum (CASTELLS, 1999).

Em pesquisa sobre cidadania e desenvolvimento local, Tenório, (2007, p.101) considera uma concepção de desenvolvimento: "como aquela possibilidade metodológica de intervenção no local, por meio da interação dialógica entre diferentes atores: sociedade civil, Estado e mercado". Para tal, investiga a cidadania pela análise de variáveis abaixo descritas, o esquema analítico de Tenório (2007) será utilizado na metodologia do estudo de caso proposto neste artigo, onde: o poder público inclui a prefeitura e a câmara de vereadores; a sociedade civil congrega as organizações civis; o mercado representado pelos empresários; a cidadania, contemplando pela atuação dos munícipes. 


\section{Aspectos metodológicos}

O primeiro passo da pesquisa quanto à obtenção de informações foi análise de documentos e leis, e suas respectivas aplicações e usos na situação estudada. Posterior a esta etapa, foram reunidos os dados estatísticos sobre o município e a região segundo as informações disponibilizadas no Instituto Brasileiro de Geografia e Estatística (IBGE), na Fundação Centro de Informação e Dados do Rio de Janeiro e no Tribunal de Contas do Estado do Rio de Janeiro (TCE-RJ). Na coleta de dados primários foi elaborada uma pesquisa de campo, no local, com entrevistas não estruturadas e depoimentos de autoridades públicas, lideranças e agentes econômicos locais. Cabe ressaltar que um dos autores desta pesquisa é observador participante, pois o mesmo é funcionário da Prefeitura Municipal de Itaguaí e suas atividades estão diretamente ligadas ao desenvolvimento municipal. Devido a sua base de atuação na prefeitura, o mesmo teve facilidade em acessar os atores locais entrevistados, além de participar de eventos que discutem o assunto, tais como, audiências públicas e seminários. No entanto, durante o estágio de elaboração de pesquisa de campo, o mesmo procurou seguir as recomendações propostas por Vergara (2009) quanto a sua isenção nas opiniões recebidas dos entrevistados ou no que se refere à facilidade de obter os dados no local.

A elaboração das entrevistas ocorreu no período de setembro a novembro de 2009, e abaixo listamos os principais atores entrevistados.

- Referentes ao Poder Público Municipal, foram entrevistados: o Secretário Municipal de Planejamento, cuja entrevista focou os aspectos referentes ao Plano Diretor, ocupação urbana; o Secretário Municipal de Obras e Urbanismo, cuja entrevista focou os aspectos referentes ao Plano Diretor, desgaste de equipamentos públicos, causados pelo incremento no uso e no aumento do tráfego de caminhões pesados devido às obras e construções em andamento; o Secretário Municipal de Meio Ambiente, Agricultura e Pesca, cuja entrevista focou os aspectos referentes à decadência da atividade pesqueira e agrícola e ocupação industrial da Ilha da madeira; a Diretora Geral do Hospital Municipal S. Francisco Xavier, cuja entrevista focou o aumento dos atendimentos a operários provenientes de outras regiões, agora trabalhadores em construção civil no município; o Administrador regional da Ilha da Madeira, cuja entrevista focou os problemas oriundos das atividades empresariais na ilha; os Vereadores, cujas entrevistas focaram a expectativas positiva e negativas em relação ao crescimento do município.

- Referentes a atores atuantes no mercado, foram entrevistados doze empresários locais, cujas entrevistas focaram como os investimentos em andamento vêm alterando seus negócios existentes antes dos investimentos atuais. Quanto ao número de empresários entrevistados, observou-se a saturação das respostas, ou seja, repostas similares dos respondentes.

- Referentes à sociedade civil foram entrevistados: o Presidente da Colônia de Pescadores da Ilha da Madeira - a entrevista focou o impacto dos investimentos na vida da colônia de pescadores e como estes estão atuando na preservação de seus direitos; dezoito participantes do $2^{\circ}$ Fórum de Itaguaí, que prestaram depoimentos sobre a sua visão e participação da sociedade civil local sobre as mudanças ocorridas na região e seus modos de participação. Observou-se também a saturação das repostas para definir o número de respondentes.

Os resultados da pesquisa de campo foram sintetizados em três quadros, que seguem o modelo proposto por Fischer (2002, p. 99-100) quanto à definição de variáveis e ou situações que foram analisadas. O primeiro quadro apresenta os resultados das opiniões dos atores entrevistados sobre a capacidade de ação destes nos processos decisórios locais; o segundo quadro avalia, na visão dos atores locais, o uso dos instrumentos legais ou instituídos de participação; o terceiro quadro sintetiza os aspectos que podem influir negativamente no desenvolvimento local. Os resultados apresentados nos quadros, quando oriundos das entrevistas, foram tratados segundo o método de análise por categorias, segundo a técnica de análise de discurso, descrita por Bardin (1977). Logo, buscou a agregação de significados das falas e dos depoimentos segundo as variáveis que foram analisadas. Segundo Gill (2003), a análise de discurso é uma leitura cuidadosa, para examinar o conteúdo, organizado em função do discurso do entrevistado ou do depoente. A análise deve respeitar os aspectos contextuais, históricos e culturais onde se situa o objeto de análise da pesquisa. 
Quanto às limitações metodológicas, além da delimitação do período temporal (2006-2010) e espacial no município de Itaguaí/RJ, a pesquisa foi focada na atuação dos poderes do local face aos impactos dos empreendimentos. A pesquisa não pretende fazer extrapolações nem elaboração de cenários, somente confronta as teorias e as práticas locais para a construção de uma análise crítica.

\section{Resultados}

Os resultados apresentados devem ser circunscritos no seguinte contexto: a partir dos anos 70, observa-se uma mudança na estrutura da economia local, antes de vocação agrícola, transforma-se gradativamente em um polo de indústria e serviços, com a disposição do governo central em incrementar a utilização do porto de Sepetiba como alternativa aos portos do Rio de Janeiro e Santos, naquele momento considerados como saturados. Tal mudança se dá no bojo dos programas Avança Brasil e Brasil em Ação. Ao longo desses anos diversos projetos foram anunciados para a região, tendo em comum a não concretização: criação de uma Zona de Processamento de Exportação (ZPE), construção do Polo Petroquímico do estado do Rio de Janeiro, construção de nova unidade da Companhia Siderúrgica Nacional e expansão do complexo industrial do porto de Sepetiba. Estes projetos contribuíram para o crescimento populacional sem que houvesse melhoria dos índices de emprego e renda (MULS, BÉCUE e MELO 2005, p. 142-148). Verifica-se que Itaguaí sempre participou como uma extensão da Região Metropolitana do Rio de Janeiro, porém tornou-se local de ocupação desordenada que reflete de certa maneira a expansão econômica da metrópole vizinha (MULS, BÉCUE e MELO 2005, p. 152).

Do ponto de vista político, há uma "oligarquia política" que se reveza no poder desde os anos 80. Esta oligarquia é composta de quatro famílias que fizeram todos os prefeitos desde os anos 70. Há também um histórico de grande violência associada à política, tendo em determinado período acontecido nove crimes fatais, iniciados com a morte de um prefeito em exercício. Tais disputas tinham como pano de fundo o controle de um recurso natural essencial à economia do município naquela época: os areais, a grande ocorrência de areia, argila, caulim e rochas com potencial para a manufatura de brita, para a construção civil (MARQUES, 2006). Segundo Alves (2003), o padrão de violência existente na baixada fluminense está relacionado a sua formação socioeconômica: a região foi historicamente usurpada pelos grandes interesses econômicos e processos autoritários, onde a resultante foi a exclusão social, a degradação ambiental, a criminalidade, entre outros efeitos perversos.

Os quadros a seguir apresentados fazem a ligação das variáveis identificadas no referencial teórico e a realidade observada na pesquisa de campo.

Quadro 1

Exame das variáveis e situação apurada referente aos atores: sociedade civil, estado e mercado

\begin{tabular}{|l|l|}
\hline \multicolumn{1}{|c|}{$\begin{array}{c}\text { Variável } \\
\text { observada }\end{array}$} & \multicolumn{1}{c|}{ Situação apurada na pesquisa de campo } \\
\hline Cidadania & $\begin{array}{l}\text { Desprestígio da atividade política, participação como degrau para a obtenção de poder, } \\
\text { democracia de baixa intensidade. } \\
\text { Não se observa participação popular ou interesse pelo desenvolvimento sustentável. } \\
\text { O desprestígio da atividade política contribui para desvalorizar o exercício da cidadania, } \\
\text { na visão popular. } \\
\text { Busca de participação no controle das políticas públicas, como meio de projeção na } \\
\text { atividade política. }\end{array}$ \\
\hline
\end{tabular}




\begin{tabular}{|c|c|}
\hline Sociedade Civil & $\begin{array}{l}\text { Valoriza a diversidade cultural em associações que não têm atuação de caráter político, } \\
\text { pelo menos de modo formal. } \\
\text { Não há ambiente cultural característico da cidade, face a uma preponderância da cultura } \\
\text { da metrópole vizinha. } \\
\text { Forte assimetria de informação com meios de comunicação utilizados para divulgação } \\
\text { política e religiosa. } \\
\text { Não foram observados sinais de que haja acompanhamento da legislação por parte de } \\
\text { organizações civis. } \\
\text { Os valores tradicionais relacionados a assistencialismo e clientelismo são fortemente } \\
\text { arraigados na atividade política. }\end{array}$ \\
\hline Poder Público & $\begin{array}{l}\text { Relatos de comprometimento do funcionalismo com a coisa pública. } \\
\text { Grande entrosamento político entre os poderes executivo, legislativo e judiciário. } \\
\text { Há um forte trabalho do governo na promoção da vocação econômica e identidade } \\
\text { local, com a associação da imagem de "Cidade do Porto" a Itaguaí. } \\
\text { Forte centralização das decisões no poder executivo, com a Câmara aparentemente } \\
\text { situando-se como instância ratificadora dos planos municipais. } \\
\text { Não foi observado forma de consulta às comunidades sobre prioridades de obras e } \\
\text { serviços públicos. } \\
\text { Grande número de obras públicas, com aumento da autoestima da população e em } \\
\text { dividendo político nas eleições. } \\
\text { Visão economicista das políticas públicas que se contrapõe ao planejamento de longo } \\
\text { prazo dos grandes empreendimentos. } \\
\text { Há forte concentração das decisões no governo, sendo que os conselhos existentes têm } \\
\text { atuação modesta. } \\
\text { Não foi observado o emprego de métodos participativos, como orçamento participativo } \\
\text { ou planejamento participativo. }\end{array}$ \\
\hline Mercado & $\begin{array}{l}\text { Tradicionalmente, as empresas têm baixo envolvimento com as questões locais. As } \\
\text { empresas exploram os recursos, porém poucos contribuem para o desenvolvimento } \\
\text { local. } \\
\text { As grandes empresas comportam-se como se fossem localizadas em um subúrbio da } \\
\text { cidade do Rio de Janeiro: seus funcionários de maiores salários moram no Rio de Janeiro } \\
\text { e muitas demandas de compras e serviços são supridas na capital. } \\
\text { As relações do mercado com o poder público podem permitir grande capacidade de } \\
\text { articulação de ações conjuntas. }\end{array}$ \\
\hline $\begin{array}{l}\text { Potenciais do } \\
\text { Território }\end{array}$ & $\begin{array}{l}\text { A infraestrutura econômica tem se movimentado para atender à demanda gerada pela } \\
\text { ativação dos grandes projetos no porto e da TKCSA, especialmente no setor de serviços. } \\
\text { A infraestrutura social, que recebe um afluxo contínuo de trabalhadores temporários } \\
\text { alocados na construção das instalações industriais, enfrenta novos desafios. } \\
\text { As demandas à infraestrutura do município ainda não estão dimensionadas, mas já } \\
\text { repercutem nos problemas trazidos pela presença de inúmeras casas transformadas em } \\
\text { alojamentos para centenas de trabalhadores. }\end{array}$ \\
\hline
\end{tabular}




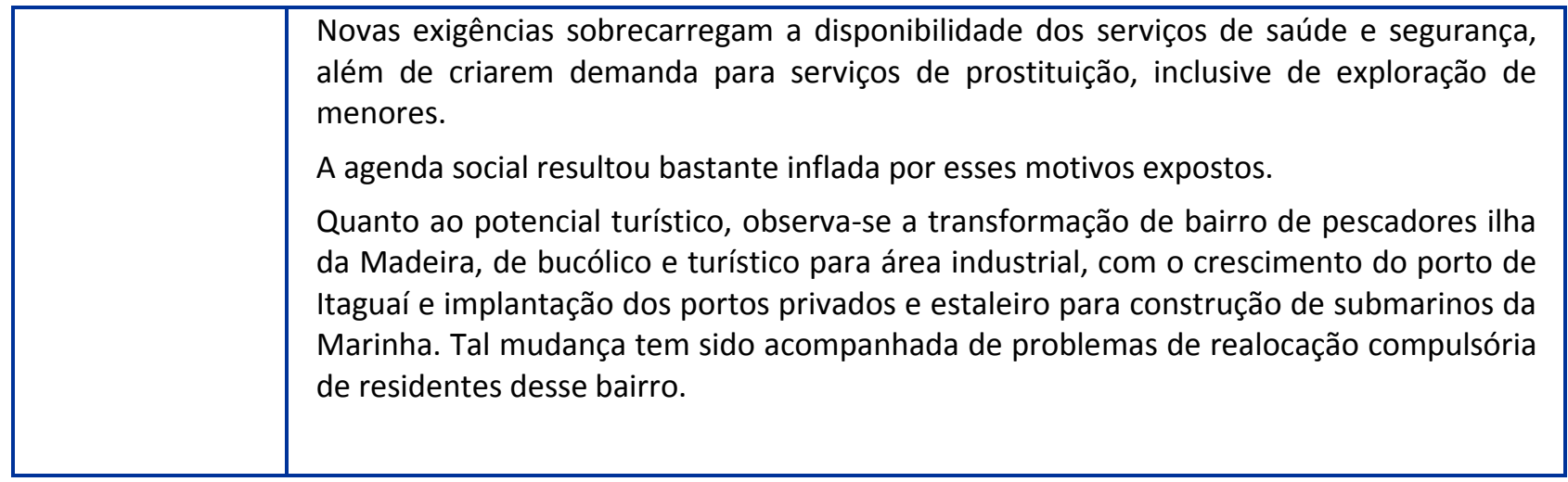

Fonte: Elaboração própria, apresentação dos resultados a partir do modelo proposto por Fischer, (2002).

O quadro 1 retrata a baixa participação dos atores locais no desenvolvimento local, o quadro 2 apresenta quais instrumentos legais e instituídos podem ser utilizados pelos atores locais. Podem-se classificar os instrumentos em três categorias conforme a origem das ações: aquelas cuja iniciativa é do Poder Público, as que são de origem de outros atores, como por exemplo: as iniciativas de controle e fiscalização por parte da Sociedade Civil e Cidadãos. Finalmente temos uma categoria que poderíamos dizer que são colaborativas ou de cooperação entre os diversos atores. Num exame da utilização ou implementação desses instrumentos, podemos verificar: o Poder Público tem dominado as iniciativas na implantação de conferências e conselhos. Também tem papel central no estabelecimento das políticas de Ensino Público e Cultura. Essa preponderância é, em parte, facilitada pela ausência de participação dos demais atores, conforme observada acima. Grande parte desses instrumentos estão amparados pela lei e se revestem de um caráter obrigatório. Possivelmente por esta razão estão implantados. A questão que emerge é que, ao serem implantados pelo governo municipal, são instrumentalizados de forma política. Instrumentos que poderiam ser utilizados para controle do governo são postos a serviço da política que está no poder. A obrigatoriedade legal de instalação dos conselhos e conferências atribuídas ao poder público se soma ao descaso pela participação pelo cidadão, além da maior capacidade dos gestores públicos, leva a uma predominância da voz do poder público.

Quanto àquelas de cunho colaborativo entre diferentes atores do poder local, como Agenda 21 Local, DLIS, Redes e Consórcios Intermunicipais, foram encontradas somente algumas iniciativas no período observado. Neste ponto é importante registrar que todos estes instrumentos apresentam características comuns. Eles estão voltados para a organização das ações de agregação de esforços do município ou da região a fim de reagirem a desafios externos (DOWBOR, 2008).

Quadro 2

\section{Verificação e aplicação dos instrumentos de participação à disposição do poder local}

\begin{tabular}{|l|l|}
\hline \multicolumn{1}{|c|}{$\begin{array}{c}\text { Instrumento de } \\
\text { participação }\end{array}$} & \multicolumn{1}{c|}{ Aplicação no local } \\
\hline Orçamento Participativo & Utilização da nomenclatura para efeitos de marketing político. \\
\hline Plano Diretor & Utilizado para indicar o zoneamento para ocupação dos espaços públicos. \\
\hline $\begin{array}{l}\text { Denúncia de } \\
\text { irregularidades }\end{array}$ & $\begin{array}{l}\text { Denúncias de improbidade administrativa contra os poderes executivo e } \\
\text { legislativo. }\end{array}$ \\
\hline
\end{tabular}




\begin{tabular}{|c|c|}
\hline Ação Popular & Sem uso registrado no município, no período pesquisado. \\
\hline $\begin{array}{l}\text { Proteção dos direitos da } \\
\text { criança e do adolescente }\end{array}$ & $\begin{array}{l}\text { Atuação conjunta do poder público, sociedade e Conselho da Criança e do } \\
\text { Adolescente. }\end{array}$ \\
\hline $\begin{array}{l}\text { Colegiado de órgãos } \\
\text { Públicos }\end{array}$ & $\begin{array}{l}\text { Não foi observada a atuação de nenhum órgão colegiado formal no governo } \\
\text { municipal. }\end{array}$ \\
\hline Cultura & $\begin{array}{l}\text { Existe alguma participação da sociedade na condução de ações culturais e } \\
\text { sociais. }\end{array}$ \\
\hline Ensino Público & $\begin{array}{l}\text { Não foi observado participação da sociedade na condução da política } \\
\text { educacional. }\end{array}$ \\
\hline Iniciativa Popular & Não observado utilização deste instrumento no período pesquisado. \\
\hline Planejamento Público & Não observado participação na utilização deste instrumento. \\
\hline Plebiscito & Não observado utilização deste instrumento no período pesquisado. \\
\hline Política Agrícola & Não observado utilização deste instrumento no período pesquisado. \\
\hline Referendo & Não observado utilização deste instrumento no período pesquisado. \\
\hline $\begin{array}{l}\text { Agência de } \\
\text { Desenvolvimento Local }\end{array}$ & Não observado utilização deste instrumento no período pesquisado. \\
\hline Agenda 21 Local & $\begin{array}{l}\text { Em andamento a iniciativa do poder público de criação de uma Agenda } 21 \\
\text { Local. }\end{array}$ \\
\hline Conferência & Cumpridas as Conferências exigidas pela legislação, com caráter técnico. \\
\hline Conselhos & Funcionam os de Saúde, de Educação e os de Assistência Social. \\
\hline Consórcio intermunicipal & $\begin{array}{l}\text { O município está em um consórcio dedicado à gestão de saúde na região } \\
\text { metropolitana. }\end{array}$ \\
\hline $\begin{array}{l}\text { DLIS -Rede de } \\
\text { Desenvolvimento Local } \\
\text { Integrado Sustentável }\end{array}$ & Não há registro de atividade DLIS no período pesquisado. \\
\hline Fóruns & $\begin{array}{l}\text { Fórum anual sobre a cooperação efetiva cidade-porto, para o } \\
\text { desenvolvimento municipal. }\end{array}$ \\
\hline Parcerias & Existem parcerias entre órgãos públicos e entidades de outras escalas. \\
\hline
\end{tabular}




\begin{tabular}{|l|l|}
\hline Plano Estratégico Local & Não foi observado emprego desse recurso no local, no período observado. \\
\hline $\begin{array}{l}\text { Polo de } \\
\text { Desenvolvimento }\end{array}$ & Divulgação política do novo Polo de Desenvolvimento da Zona Oeste e Itaguaí. \\
\hline Redes & Não foi observada a existência de redes formais, no período pesquisado. \\
\hline
\end{tabular}

Fonte: Elaboração própria, apresentação dos resultados seguindo o modelo proposto por FISCHER (2002).

No caso em tela, verificamos que grande parte da iniciativa das ações do poder local tem origem no poder público. Por força das limitações políticas referentes aos mandatos dos administradores, quatro anos com possibilidade de reeleição, as estratégias do governo são moldadas neste aspecto temporal. Essa limitação que busca a alternância no poder, somada à cultura política no Brasil, restringe a continuidade administrativa, dificultando a formação de políticas de longo prazo bem como a formação de quadros ou redes que enfrentem desafios de longo prazo.

No aspecto referente às escalas de atuação do poder local, observa-se que a chamada "máquina pública" está voltada para uma atuação interna e para argumentação com o poder público estadual e federal, principalmente para obtenção de recursos. No caso de enfrentamento de demandas de nível técnico com grandes empresas, como por exemplo, a TKCSA, o governo local não está qualificado para trabalhar nessas questões numa relação dialógica na mesa de negociação, principalmente porque não se preparou ou não foi apoiado quando necessário. $\mathrm{O}$ fato de não se ter preparado não é um julgamento da atuação, e sim uma constatação do fato de que a grande empresa trabalha num horizonte temporal de planejamento e execução totalmente diferente do governo local. O que se verifica é que as necessidades e consequências que hoje ocorrem no local onde está instalada a TKCSA poderiam ser previstas anos antes do início da construção. O governo local só sabe que vai receber tal empreendimento pouco antes do início das obras. Um exemplo concreto é a questão da poluição: a empresa tem em seu capital de conhecimento tudo sobre as consequências e sobre como lidar com tal problema, pelo menos no que lhe interessa, o governo local sabe da amplitude do problema pelos jornais ou por qualquer outro meio, mas quando já há decisão do governo federal quanto à instalação naquele local (DELMAS e BRANDÃO, 2009).

Otavio (2011), em matéria do jornal O Globo intitulada "O ' $\mathrm{X}$ ' do negócio", denuncia o modelo pelo qual a empresa MMX atua em Itaguaí. Uma transação imobiliária explicita o envolvimento de autoridades públicas com os interesses empresariais. Neste sentido, a matéria explicita como a comunidade local se tornou vítima de processos onde os mesmos não encontram apoio em seus representantes locais. Informações privilegiadas, uso dos instrumentos de poder público para fins particulares colocam em extinção a comunidade de pescadores onde o porto da MMX está se instalando. Tal matéria de jornal corrobora os resultados encontrados nesta pesquisa, acima citados: fraca participação popular, poder público não articulado com a sociedade local e fraca discussão dos processos de desenvolvimento local.

As necessidades e consequências da instalação destas grandes empresas são fatores que vão se desdobrar nos próximos anos, talvez com choque entre os interesses dos diferentes grupos. Possivelmente uma grande indústria siderúrgica não tem o mesmo impacto social que um estaleiro ou porto. Apesar de terem caráter complementar, a implantação conjunta num mesmo local pode potencializar os efeitos. Nos aspectos negativos associados ao conceito de desenvolvimento local, elencados por Tânia Fischer podemos observar: 
Quadro 3

Fatores que podem impactar negativamente no desenvolvimento local

\begin{tabular}{|l|l|}
\hline \multicolumn{1}{|c|}{ Fatores que podem impactar negativamente } & \multicolumn{1}{|c|}{ Observação da pesquisa } \\
\hline $\begin{array}{l}\text { Desgaste conceitual do termo “desenvolvimento } \\
\text { local” }\end{array}$ & $\begin{array}{l}\text { A expressão usada pela mídia como sinônimo de } \\
\text { crescimento econômico. }\end{array}$ \\
\hline Desgaste dos métodos participativos & $\begin{array}{l}\text { Fraca ou germinal capacitação local em métodos } \\
\text { participativos. As atividades participativas são } \\
\text { conduzidas pelo governo local. }\end{array}$ \\
\hline Ineficácia ante limites concretos de poder & $\begin{array}{l}\text { As atividades comunitárias têm forte dependência } \\
\text { do governo local. }\end{array}$ \\
\hline $\begin{array}{l}\text { Descontinuidade política e as interferências político- } \\
\text { partidárias locais }\end{array}$ & $\begin{array}{l}\text { A troca do mandatário altera o apoio e } \\
\text { continuidade de iniciativas locais. }\end{array}$ \\
\hline $\begin{array}{l}\text { Dificuldades de articulação entre instâncias de } \\
\text { governo e sociedade }\end{array}$ & $\begin{array}{l}\text { Fraca articulação dos poderes locais e sociedade } \\
\text { civil. }\end{array}$ \\
\hline $\begin{array}{l}\text { Tendência à construção "externa" das estratégias } \\
\text { de desenvolvimento local }\end{array}$ & $\begin{array}{l}\text { Toda estratégia de desenvolvimento local foi } \\
\text { planejada em outras esferas que não a esfera } \\
\text { local. }\end{array}$ \\
\hline $\begin{array}{l}\text { Fragilidades metodológicas dos tipos de intervenção } \\
\text { em desenvolvimento local }\end{array}$ & Fraca intervenção dos poderes locais. \\
\hline $\begin{array}{l}\text { Criação de dependências nas comunidades } \\
\text { promotoras do desenvolvimento local }\end{array}$ & $\begin{array}{l}\text { A gestão governamental das atividades } \\
\text { participativas estabelece a dependência. }\end{array}$ \\
\hline $\begin{array}{l}\text { Superposição de programas e projetos de diferentes } \\
\text { instituições }\end{array}$ & Não observado na pesquisa. \\
\hline $\begin{array}{l}\text { resultação inexistente ou inadequada dos processos, } \\
\text { Nampactos }\end{array}$ & $\begin{array}{l}\text { Não foi observada uma avaliação isenta dos } \\
\text { processos, resultados e impactos. }\end{array}$ \\
\hline
\end{tabular}

Fonte: Elaboração própria, apresentação dos resultados seguindo o modelo proposto por FISCHER

(2002, p. 99-100).

Com relação à gestão social, há um déficit de participação histórico e anterior à implantação dos projetos atuais. Já no projeto de implantação do porto de Itaguaí, à época com nome de porto de Sepetiba, houve baixo envolvimento dos atores locais, tanto sociedade como poder público municipal (MULS, BÉCUE e MELO, 2005 p. 203-209).

Examinando os requisitos básicos colocados por Llorens (apud TENÓRIO, 2002), a pesquisa identificou alguns pontos relevantes. O poder público tem tomado iniciativa em alguns aspectos: reorganização da base empresarial; desenvolvimento de infraestrutura básica, mediante saneamento, asfaltamento de vias de acesso aos principais locais de empreendimentos, busca de convênios com instituições e órgãos públicos de outras 
escalas para capacitação de recursos humanos, como por exemplo, a instalação de instituições de ensino técnico como Centro Federal de Educação Tecnológica (CEFET) e Fundação de Apoio à Escola Técnica do Rio de Janeiro (FAETEC- RJ).

\section{Considerações finais}

A relevância do tema está ligada ao fato de que tal ocorrência, grande empreendimento apoiado pelo poder central em local com histórico econômico sem grande dinamismo econômico e/ou empreendimentos anteriores, está presente em vários dentre os noventa e dois municípios do Estado do Rio de Janeiro: o Complexo Petroquímico da Petrobrás do Rio de Janeiro em Itaboraí, a Usina Termelétrica de Angra 3 em Angra dos Reis, Usina Termelétrica do Açu e Complexo Portuário do Açu em S. João da Barra, os empreendimentos citados em Itaguaí e diversos outros de menor monta, mas cuja presença traz enormes desafios ao local. Segundo o TCE-RJ (2008), existem cinco empreendimentos acima de 1 bilhão de reais em municípios do Rio de Janeiro, no momento. A implantação de grandes projetos é decidida e implementada sem a participação do poder local que normalmente não está capacitado para equacionar possíveis encaminhamentos que reduzam as negatividades dos impactos. Esses grandes projetos, por sua vez, quase sempre, não estão relacionados com o desenvolvimento prévio da região, como é o caso em análise.

Há uma grande assimetria informacional e de poder, na medida em que a grande empresa tem um corpo técnico/gerencial e uma estrutura permanente que pensa e age de forma estratégica em cima dos pontos do território que lhe interessam, tirando partido de menores custos (mão de obra ou energia), fatores locacionais ou qualquer outra variável que maximize sua rentabilidade. O poder público, ao contrário, está sujeito a descontinuidades, processo eleitoral e principalmente no caso do poder local, está desaparelhado para enfrentar os desafios técnicos e políticos representados pelos projetos.

Outro aspecto importante é a difícil e complexa relação entre as escalas de poder e suas atribuições, ou seja: municípios, estados e união. Para além da questão das competências, é visível a falta de quadros e de uma política efetiva nas estruturas que deveriam agir em apoio às localidades atingidas, como é o caso do Ministério das Cidades, Secretarias de Estado.

Ao considerarmos os diversos instrumentos de participação, que permitem aos atores sociais atuarem no desenvolvimento local, verifica-se que no caso de Itaguaí, ou não foram utilizados ou o são a reboque de uma atuação do poder público, mais capacitado e dominante.

É possível observar que tais instrumentos são quase todos voltados para uma atuação endógena, para o controle das atividades exercidas pelo poder público e seus administradores. Claro que é salutar a existência de tais ferramentas, mas verificamos que no caso em tela, são insuficientes e talvez incapazes de lidar com a complexidade de grandes investimentos e com as ferramentas e instrumentos de planejamento, controle e execução de ações que estão à disposição desses gestores. São adequadas para lidar com atuação do prefeito, do vereador, do gestor público e com as questões de caráter local. A esse aspecto soma-se o fato de que tudo no âmbito do poder público gira em torno do orçamento, de caráter anual, e o planejamento tem as limitações inerentes ao mandato dos governantes, que é de quatro anos.

O Plano Diretor poderia talvez ser um instrumento que fizesse frente a um planejamento de mais longo prazo, porém isso não acontece. É usado como delimitador e orientador da ocupação urbana, naqueles municípios com população superior a vinte mil habitantes. É preciso que se diga que tal função não é de pouca importância na via do município. Apenas não é suficiente para os desafios postos por grandes empreendimentos. 
De certa forma, essa limitação é recorrente em outros instrumentos. Provavelmente, isso decorre do fato de que a lei estabelece tais regras para os quase seis mil municípios espalhados pelo país, com todos os matizes e variações possíveis. Afinal, megaempreendimentos não são tão comuns assim em tal variedade de cidades.

Não se pode esquecer de que o movimento do capital em busca da vantagem comparativa e da viabilidade do lucro, aliado ao grande impulso desenvolvimentista insuflado pelo governo federal, com o Programa de Aceleração do Crescimento (PAC), tem trazido inúmeros desafios a comunidades não organizadas para se precaverem quanto aos seus efeitos nocivos.

Há que se buscar melhorias no processo de desenvolvimento local, com apoio de órgãos públicos voltados para o problema, órgãos não governamentais especializados e outras formas possíveis, de modo a disponibilizar uma capacidade de apoio àqueles municípios que estejam vivendo tais desafios. $\mathrm{O}$ desenvolvimento do local pode dar campo ao desenvolvimento da qualidade de vida local, da comunidade, dos atores locais. O que é preciso é que o poder local tenha acesso aos instrumentos políticos, gerenciais e financeiros para requisitar e fiscalizar a justa participação nos resultados da intervenção dos megaempreendimentos nos recursos do local e não apenas deva sustentar os custos socioambientais.

Face à conclusão de que os instrumentos disponíveis ao poder local para conviver com grandes empreendimentos não são suficientes para esse desafio, espera-se que os estudos no campo continuem e possam trazer novos conceitos e capacidades ao processo de desenvolvimento local justo para essas cidades.

\section{Referências}

ACSElROD, H. Território e Poder - a política das escalas. In: Tania Fisher. (Org.). Gestão do Desenvolvimento e Poderes Locais - marcos teóricos e avaliação. Salvador: Casa da Qualidade, 2002, v. 1, p. 33-44.

ALBUQUERQUE, F. Desarollo economico local y Descentralización en America Latina. Revista de la CEPAL. No. 82, Abril de 2004, p.157-171.

ALVES, J.C.S. Dos barões ao extermínio- uma história da violência na baixada fluminense. Duque de Caxias: APPH,CLIO, 2003.

BARDIN, L. Análise de Conteúdo. Lisboa: Edições 70, 1977.

BRASIL.Constituição da República Federativa do Brasil, Presidência da Republica, disponível em < http://www.planalto.gov.br/ccivil_03/constituicao/constitui\%C3\%A7ao.htm> acesso em 15/08/ 2011.

BRESSER-PEREIRA, L.C. Desenvolvimento e crise no Brasil: história, economia e política de Getúlio Vargas a Lula. 5.ed. São Paulo: Editora 34, 2003.

BUENO, J. Com a instalação da TKCSA, abre-se caminho para instalação de um polo metal-mecânico naquela área. Rio de Janeiro: Jornal dos Economistas. N N $^{\circ} 39$ JUNHO DE 2009. Disponível em <http://www.coreconrj.org.br/pdf/JE_junho2009.pdf>. Acesso em 20/02/2010.

CALDAS, E.; MARTINS, R. Visões do Desenvolvimento Local: uma análise de experiências brasileiras. Rio de Janeiro: Anais do I Encontro Nacional de Administração Pública e Governança da Associação Nacional de Pósgraduação e Pesquisa em Administração (ANPAD); CD-ROM, 2004. Disponível em <http://www.polis.org.br/download/55.pdf > Acesso em 22/02/2010.

CARAMELO, J.; CORREIA, J. A. Políticas e figuras do local: Contributos para a construção de um cosmopolitismo comunitário. Cadernos do ICE, 7. Universidade do Porto. Porto: 2004. Disponível em <http://www.fpce.up.pt/ciie/jacorreia_ICE-7.pdf>. Acesso em 18/04/2010. 
CARvalho, M. do C. A. Participação social no Brasil hoje. Polis papers, n. 02, 1998. Disponível <HTTP://www.polis.org.br/publicacoes/papers/19982.html>. Acesso em 20/03/2010.

CASTELLS, M. Sociedade em rede. 5. ed. São Paulo: Paz e Terra, 1999.

CIDE-RJ - Fundação Centro de Informações e Dados do Estado do Rio de Janeiro - Rio de Janeiro em dados. Disponível em < http://www.cide.rj.gov.br/tabelas/IDH_1991_2000_RJ.xls>. Acesso em 23/02/2010.

DELMAS, M. F.; BRANDÃO, T. CSA vai compensar emissão de gases-estufa. O Globo, Rio de Janeiro, Meio Ambiente, 25 nov. 2009.

DOWBOR, L. O Que é Poder Local? Junho 2008. Disponível em < http://www.dowbor.org/poder_local.asp >. Acesso em $20 / 02 / 2010$

DUBKE, A. F.; FERREIRA, F. R. N. PIZZOLATO, N. D. Plataformas Logísticas: características e tendências para o Brasil. XXIV ENEGEP. Florianópolis, SC. 03 a 05 de novembro de 2004 . Disponível em < http://logisticatotal.com.br/files/articles/f258563065b07f63e42e4ba83d591578.pdf>. Acesso em 26/06/2009.

FISCHER, T. (Org.). Poderes locais, desenvolvimento e gestão. Introdução a uma agenda. In: Gestão do Desenvolvimento e Poderes Locais - marcos teóricos e avaliação. Salvador: Casa da Qualidade, 2002.

FÓRUM De ITAGuAí, 2º A Integração Porto-Cidade, Veículo para a Sustentabilidade. Itaguaí, 06/08/2009. Disponível em <http://saberglobal.com.br/itaguai/index3.html>. Acesso em 20/03/2010.

FRANÇA, R. L. O Plano Diretor como Instrumento de Controle Social. Rio de Janeiro, 2006. Disponível em < http://siga.ecg.tce.rj.gov.br/upload_arquivos/ricardo\%20luis\%20fran\%c3\%a7a.pdf > Acesso em 21/03/2009.

FURTADO, C. Introdução ao Desenvolvimento. Enfoque Histórico-estrutural. Rio de Janeiro: Paz e Terra, 2000.

GARCES, A.; SILVEIRA, J. P. Gestão pública orientada para resultados no Brasil. Revista do Serviço Público, Ano 53, n. 4, Out-Dez 2002.

GILL, R. Análise de discurso. In: BAUER, Martin W.; GASKELL, George. Pesquisa qualitativa com texto, imagem e som: um manual prático. 2.ed. Petrópolis: Vozes, 2003.

GONÇALVES, R. Economia Política Internacional: fundamentos teóricos e as relações internacionais do Brasil. Rio de Janeiro: Elsevier, 2005.

IBGE. Instituto Brasileiro de Geografia e Estatística. Tabela População por Município. 2010. Disponível em < http://www.ibge.gov.br/home/estatistica/populacao/censo2010/tabelas_pdf/total_populacao_rio_de_janeiro > Acesso em $12 / 02 / 2010$.

KRUGMAN, P. Geography and Trade. Cambridge, Massachucetts: MIT Press, 1991.

LEVY, E. Ganhar e ganhar: estratégias de negociação bem sucedidas entre os municípios, os estados e a União. In: CACCIA-BAVA, PAULICS, V.; SPINK, P. (Org.) Novos contornos da gestão local: conceitos em construção. São Paulo: Pólis, 2002.

LLORENS, F. A. Desenvolvimento econômico local: caminhos e desafios para a construção de uma nova agenda política. Rio de Janeiro: BNDES, 2001.

LOLLO, J. A.; RÖHM, S. A. Aspectos negligenciados em estudos de impacto de vizinhança. Estudos Geográficos, Rio Claro, 3(2):31- 45 , Dezembro - 2005 Disponível em <www.rc.unesp.br/igce/grad/geografia/revista.htm>. Acesso em 20/02/2010.

MARQUES, E. D. Hidrogeoquímica nas cavas de extração de areia na região do bairro piranema - distrito areeiro de Seropédica-Itaguaí - RJ. Dissertação de Mestrado apresentada ao Curso de Pós-Graduação em Geoquímica da UFF. 
Rio de Janeiro: 2006. Disponível em < http://www.cprm.gov.br/publique/media/mestra_eduardo_marques.pdf > Acesso em 15/01/2010.

MMA - Ministério do Meio Ambiente. Agenda 21 brasileira. 2004. Disponível em < http://www.mma.gov.br/sitio/index.php?ido=conteudo.monta\&idEstrutura=18\&idConteudo=10068\&idMenu=10683 > Acesso em 20/02/2010.

MULS, L.; BÉCUE, M.; MELO, L. M. Itaguaí: o dinamismo do porto nacional com ou sem desenvolvimento local. In: FAurÉ, Y. HASENCLEVER, L. (Org.) O Desenvolvimento local no Estado do Rio de Janeiro - Estudos Avançados nas realidades Municipais. Rio de Janeiro: E-papers, 2005.

OLIVEIRA, F. Aproximações ao Enigma: que quer dizer desenvolvimento local? In: CACCIA-BAVA, S.; PAULICS, V.; SPINK, P. (Org.) Novos contornos da gestão local: conceitos em construção. São Paulo: Pólis, 2002.

OTAVIO, C. O ‘x’ do negócio, Caderno de economia, O Globo, p.33, 12 jun. 2011.

PERICO, R. E. Identidades e Territórios no Brasil. Brasília: IICA, 2009.

PIRES, B. de O.; PEDLOWSKI, M. A. Impactos socioambientais de mega-empreendimentos: o caso do complexo portuário da Barra do Açu/RJ. XIV Congresso Brasileiro de Sociologia 28 a 31 de julho de 2009, UFRJ, Rio de Janeiro, RJ. Disponível em <http://starline.dnsalias.com:8080/sbs/arquivos/15_6_2009_22_19_15.pdf. Acesso em 10/02/2010.

RIO DE JANEIRO. Tribunal de Contas do Estado. Estudos Sócio-Econômicos dos Municípios do Estado do Rio do Rio de Janeiro. Comparativo dos Municípios Fluminenses. 2009. Disponível em < http://www.tce.rj.gov.br/main.asp?View= \{3E2EC6C4-7885-4703-BF6D-A590430CFD4D $\} \&$ params=pMunicipio=21 $>$. Acesso em 22/03/2010.

TENÓRIO, F.G. Gestão pública ou gestão social? Um estudo de caso. VII Congreso Internacional del CLAD sobre la Reforma del Estado y de la Administración Pública, Lisboa, Portugal, 8-11 Oct. 2002. Disponível em < http://unpan1.un.org/intradoc/groups/public/documents/CLAD/clad0044562.pdf >. Acesso em 12/05/2010.

(Org). Cidadania e Desenvolvimento Local. Ijuí: Unijuí, 2007.

. Gestão Social: uma Réplica. Revista ADM.MADE, ano 9, v.13, n.2, p.1-4, maio/agosto, 2009. Disponível em < http://revistaadmmade.estacio.br/index.php/admmade/article/view/37/29. Acesso em 23/02/2010> .

VAINER, C. B. As escalas do poder e o poder das escalas: o que pode o poder local? Cadernos IPPUR. Ano XV, No. 2, Ago-Dez 2001. Rio de Janeiro: UFRJ/IPPUR, 2001.

VERGARA, S. C. Métodos de coleta de dados no campo. São Paulo: Atlas, 2009. 